\title{
Effect of excessive iodine exposure on the placental deiodinase activities and Hoxc 8 expression during mouse embryogenesis
}

\author{
Xue F. Yang, Jian Xu, Huai L. Guo, Xiao H. Hou, Li P. Hao, Lie G. Liu and Xiu F. Sun* \\ Department of Nutrition and Food Hygiene and MOE Key Laboratory of Environment and Health, School of Public Health, Tongji \\ Medical College, Huazhong University of Science and Technology, Wuhan 430030, Hubei, China
}

(Received 12 July 2006 - Revised 8 December 2006 - Accepted 11 December 2006)

\begin{abstract}
Excessive iodine induces thyroid dysfunction. However, the effect of excessive iodine exposure on maternal-fetal thyroid hormone metabolism and on the expression of genes involved in differentiation, growth and development is poorly understood. Since a thyroid hormone receptor response element was found in the $H o x c 8$ promoter region, $H o x c 8$ expression possibly regulated by excessive iodine exposure was firstly investigated. In the present study, Balb/C mice were given different doses of iodine in the form of potassium iodate $\left(\mathrm{KIO}_{3}\right)$ at the levels of $0($ sterile water), $1.5,3.0,6.0,12.0$ and $24.0 \mu \mathrm{g} / \mathrm{ml}$ in drinking water for 4 months, then were mated. On $12.5 \mathrm{~d}$ postcoitum, placental type 2 and type 3 deiodinase activities and fetal Hoxc 8 expression were determined. The results showed that excessive iodine exposure above $1.5 \mu \mathrm{g} / \mathrm{ml} \mathrm{resulted}$ in an increase of total thyroxine and a decrease of total triiodothyronine in the serum of maternal mice, which was mainly associated with the inhibition of type 1 deiodinase activity in liver and kidney. Placental type 2 deiodinase activity decreased, showing an inverse relationship with maternal thyroxine level. Hoxc8 mRNA and protein expression at $12.5 \mathrm{~d}$ postcoitum embryos were down regulated. Because Hoxc 8 plays an important role in normal skeletal development, this finding provides a possible explanation for the skeletal malformation induced by excessive iodine exposure and also provides a new clue to study the relationship between iodine or thyroid hormones and Hox gene expression pattern.
\end{abstract}

Excessive iodine: Deiodinase: Hoxc8

Adequate iodine intake is essential for fetal and postnatal development. Iodine deficiency during pregnancy may result in in utero hypothyroidism and increase the rates of miscarriage, stillbirths, as well as congenital abnormalities such as cretinism, a grave irreversible form of mental retardation (Glinoer, 1997; Utiger, 1999). The goal of eliminating iodine-deficiency disease has been achieved since universal salt iodisation policy has been widely carried out in many nations including China (Delange \& Lecomte, 2000). On the other hand, reports are increasingly appearing on the toxic effects caused by high amounts of iodine intake. Exposure to excessive iodine occurs via food (Konno et al. 1994), drinking water (Zhao et al. 1998), medication (Martino et al. 2001) and iodised salt or iodinated oil (Wolff, 2001). Recent studies have reported that iodine excess also causes either hypothyroidism or hyperthyroidism (Markou et al. 2001; Roti \& Uberti, 2001), which may induce embryo toxicity, especially skeletal anomalies. Though little is known about the cellular and molecular basis for these abnormalities, disruption of thyroid hormone metabolism and modulation of the expression pattern of genes involved in differentiation, growth and metabolism mediated by thyroid hormones may play a pivotal role in this process.
Excessive iodine has a complex disruptive effect on thyroid hormone metabolism. Animal studies (Bednarczuk et al. 1993) have suggested that excessive iodine-induced thyroid hormone abnormalities are related to the inhibition of the activity of type 1 deiodinase (D1), which catalyses the deiodination of both the outer and inner rings of thyroxine $\left(\mathrm{T}_{4}\right)$ and is responsible for most of the circulating triiodothyronine $\left(\mathrm{T}_{3}\right)$ (Bianco et al. 2002). Fetal thyroid hormones must come from the maternal circulation before the fetal thyroid gland and pituitary-thyroid axis become functional (Obregon et al. 1984). The maternal transfer of $\mathrm{T}_{4}$ constitutes a major fraction of fetal thyroid hormones, even after the onset of fetal thyroid secretion (Morreale de Escobar et al. 1985; Burrow et al. 1994; Santini et al. 1999). Therefore, the changes of maternal thyroid hormone level have an affirmative effect on the fetus by deiodination of iodothyronines through the placenta. Placental type 2 deiodinase (D2), which mainly catalyses the outer ring deiodination of $\mathrm{T}_{4}$, and type 3 deiodinase (D3), which inactivates $\mathrm{T}_{4}$ and $\mathrm{T}_{3}$, may have an important function in regulating fetal thyroid hormone levels. However, the effect of maternal excessive iodine exposure on placental D2 and D3 activity has not been reported.

Hox genes, namely homeobox-containing genes, are a cluster of genes which encode transcriptional factors regulating

\footnotetext{
Abbreviations: D1, type 1 deiodinase; D2, type 2 deiodinase; D3, type 3 deiodinase; dpc, days postcoitum; GAPDH, glyceraldehyde-3-phosphate dehydrogenase; $\mathrm{T}_{3}$, triiodothyronine; $\mathrm{T}_{4}$, thyroxine; $\mathrm{TR}$, thyroid hormone receptor.

* Corresponding author: Professor Xiu F. Sun, fax +86 2783693307, email sunxf@mails.tjmu.edu.cn
} 
many aspects of development. Expression patterns of Hox genes are characterised by spatial collinearity, temporal collinearity and retinoic acid sensitivity collinearity (Lufkin, 1996; Martinez \& Amemiya, 2002). Thyroid hormone receptor (TR) and retinoic acid receptor have been shown to share an identical P-box sequence, which implicates that they can bind the same DNA sequences and can interact physically (Kumar \& Thompson, 1999). In frog embryogenesis, TR can modulate retinoic acid-mediated axis formation, and small changes in levels of TR in early embryos may directly affect the retinoic acid responsiveness of Xhox.lab2. In addition, PCR assays have shown that $\mathrm{T}_{3}$ can induce the expression of Xhox.lab2 in embryos which ectopically expressed $\mathrm{TR} \alpha$ (Banker \& Eisenman, 1993). However, little information is available in the literature on Hox genes expression regulated directly by thyroid hormones in mammals. The structural analysis of Hox3.1 (Hoxc8) transcription unit and the Hox3.2-Hox3.1 intergenic region found that there is a thyroid hormone response element in the transcriptional regulation region of the mouse Hoxc8 gene (Awgulewitsch et al. 1990), which implicated that thyroid hormones may regulate Hoxc8 expression during mouse embryogenesis.

Hoxc8 belongs to the Hox gene family and expresses in limbs, backbone rudiments, the neural tube of mouse mid-gestation embryos, and in the cartilage and skeleton of newborns (Kwon et al. 2005). Skeletal abnormalities in ribs, sternum and vertebrae have been observed in Hoxc8 knockout mice (Akker et al. 2001; Juan \& Ruddle, 2003). These findings suggested that Hoxc8 is an important regulator of pattern formation during the development of the vertebrate skeleton. Our laboratory has previously illustrated (Yang et al. 2006) that maternal excessive iodine exposure resulted in defects in skeletal patterning in fetuses, such as supernumerary ribs, agenesis of sternbrae, poor ossification of metacarpals and metatarsals and distortion of vertebrae. Such alternations induced by excessive iodine may be related to the modulation of Hoxc8 expression by thyroid hormones. However, little in the literature was available on this hypothesis. Therefore, we conducted the present study to determine whether maternal and fetal thyroid hormone metabolism was influenced, and whether Hoxc 8 expression pattern was regulated by excessive iodine exposure during mouse embryogenesis.

\section{Materials and methods}

\section{Animals and treatment}

Weaning Balb/C mice obtained from the Laboratory Animal Centre of Hubei Provincial Centre for Disease Control and Prevention (Wuhan, China) were maintained in constant temperature-controlled rooms $\left(22 \pm 2{ }^{\circ} \mathrm{C}\right)$ with controlled lighting (12 h light-dark cycle). All animals were housed in stainless steel cages and given a commercial laboratory chow and sterile water ad libitum. The content of iodine in the diet and water was $365 \mu \mathrm{g} / \mathrm{kg}$ and $8 \mu \mathrm{g} / \mathrm{l}$ respectively. The animals were cared for according to the Guiding Principles in the Care and Use of Animals. The experiments were approved by the Tongji Medical College Council on Animal Care Committee.

After acclimatisation to the laboratory environment for 1 week, animals were randomly assigned to six groups of twelve animals each (eight females and four males) according to body weight and given different doses of iodine in the form of potassium iodate $\left(\mathrm{KIO}_{3}\right)$ in the drinking water at the levels of $0,1 \cdot 5,3 \cdot 0,6 \cdot 0,12 \cdot 0$ and $24 \cdot 0 \mu \mathrm{g} / \mathrm{ml}$ by using sterile water as the vehicle. Water consumption of each group was recorded. Female mice were placed into the metabolism cages, 4 months later, of four mice each and urine samples of $3 \mathrm{~h}$ in the morning were collected for $3 \mathrm{~d}$ for urinary iodine concentration determination. Then females were paired with a male in a 2:1 ratio overnight and examined for the presence of a vaginal plug in the following morning, which was defined as 0.5 days postcoitum $(\mathrm{dpc})$. The treatment with high doses of iodine continued through the period of gestation. Dams were killed by cervical dislocation on $12.5 \mathrm{dpc}$ and blood was collected for thyroid hormone analysis. Placentas were collected immediately, frozen in liquid $\mathrm{N} 2$ and stored at $-80^{\circ} \mathrm{C}$ for D2 and D3 activity determination. Embryos were dissected free of the maternal and extra-embryonic tissue in PBS, then frozen in liquid $\mathrm{N}_{2}$ and stored at $-80^{\circ} \mathrm{C}$ for RT-PCR and Western analysis.

\section{Iodine concentration and thyroid hormone analysis}

Iodine concentration in diet, water and urine was measured by the Cer-Arsenite colorimetric method as modified by Fischer et al. (1986). Urinary creatinine concentrations were determined by the alkaline picrate method. The urinary iodine:creatinine ratio $(\mu \mathrm{g} / \mathrm{g} \mathrm{Cr})$ was used to estimate urinary iodine concentration. Serum total $\mathrm{T}_{4}$ and total $\mathrm{T}_{3}$ were measured by RIA kits obtained from the Chinese Academy of Atomic Energy (Beijing, China).

\section{Hepatic and renal type 1 deiodinase activity assays}

Tissues were homogenised in cold hydroxyethyl piperazine ethanesulfonic acid buffer solution (dithiothreitol (1 mmol/l), hydroxyethyl piperazine ethanesulfonic acid buffer (10 mmol/l), pH 7.0, sucrose $(320 \mathrm{mmol} / \mathrm{l}))$ at a $1: 39$ and 1:24 dilution (w/v) for livers and kidneys, respectively. Homogenates were centrifuged at $1500 \mathrm{~g}$ for $10 \mathrm{~min}$ at $4^{\circ} \mathrm{C}$. The supernatant fraction was re-centrifuged at $20000 \mathrm{~g}$ for $5 \mathrm{~min}$ at $4^{\circ} \mathrm{C}$, floating debris removed and supernatant fraction used for D1 assay.

D1 activity was measured using $\left[{ }^{125} \mathrm{I}\right] 5^{\prime}-\mathrm{rT}_{3}(0.005 \mu \mathrm{mol}$ $\left[{ }^{125} \mathrm{I}\right] 5-\mathrm{rT}_{3} / 1,1000 \mu \mathrm{Ci} / \mu \mathrm{g}$; Northern Biotechnology Ltd, Beijing, China; and 0.495 $\mu \mathrm{mol} \mathrm{5}^{\prime}-1-\mathrm{rT}_{3} / \mathrm{l}$; Sigma, St Louis, MO, USA) as substrate and in the presence of dithiothreitol $(2 \mathrm{mmol} / \mathrm{l})$, EDTA $(1 \mathrm{mmol} / \mathrm{l})$ and potassium phosphate buffer $(100 \mathrm{mmol} / \mathrm{l})$, pH 7.0, based on methods previously described (Hotz et al. 1996). Enzyme activity was expressed as $\mathrm{pmol}$ of $\mathrm{I}^{-}$released/mg protein per min of reaction. Protein concentrations were determined using the method of Bradford (1976).

\section{Placental type 2 and type 3 deiodinase activity assays}

Placentas were homogenised at a 1:4 (w/v) dilution in hydro-

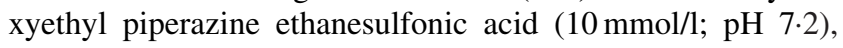
sucrose $(250 \mathrm{mmol} / \mathrm{l})$ and dithiothreitol $(10 \mathrm{mmol} / \mathrm{l})$. Homogenates were stored at $-80^{\circ} \mathrm{C}$ until further use. The measurement of D3 and D2 specific enzyme activities were performed 
as described previously (Koopdonk-Kool et al. 1996). In short, D3 activity was determined using $\left[{ }^{125} \mathrm{I}\right] 5-\mathrm{T}_{3}\left(0 \cdot 6 \mathrm{nmol}\left[{ }^{125} \mathrm{I}\right] 5-\right.$ $\mathrm{T}_{3} / \mathrm{l}, 2000 \mu \mathrm{Ci} / \mu \mathrm{g}$; Northern Biotechnology Ltd, Beijing, China; and $1 \mathrm{nmol} \mathrm{T}_{3} / 1$; Sigma) as substrate, measured by the amount of $\mathrm{I}^{-}$released in the conversion of $\left[{ }^{125} \mathrm{I}\right] 5-\mathrm{T}_{3}$ to diiodotyrosine by placental homogenates, and was corrected for non-enzymic 5-deiodination. D2 activity was determined using $\left[{ }^{125} \mathrm{I}\right] 5^{\prime}-\mathrm{T}_{4}\left(0 \cdot 3 \mathrm{nmol}\left[{ }^{125} \mathrm{I}\right] 5^{\prime}-\mathrm{T}_{4} / 1,2000 \mu \mathrm{Ci} / \mu \mathrm{g}\right.$; Northern Biotechnology Ltd; and $1 \mathrm{nmol} \mathrm{T}_{4} / \mathrm{l}$; Sigma) as substrate, measured by the amount of $\mathrm{I}^{-}$released in the conversion of $\left[{ }^{125} \mathrm{I}\right] 5^{\prime}-\mathrm{T}_{4}$ to $\mathrm{T}_{3}$ and also corrected for non-enzymic deiodination; further deiodination was inhibited by adding excess nonradioactive $\mathrm{T}_{3}$ (Sigma). Enzyme activities were expressed as fmol of $125 \mathrm{I}^{-}$released from $\left[{ }^{125} \mathrm{I}\right] 5^{\prime}-\mathrm{T}_{4}$ (D2) or $\left[{ }^{125} \mathrm{I}\right] 5-\mathrm{T}_{3}$ (D3)/h per mg protein. Protein concentrations were determined using the method of Bradford (1976), with bovine serum albumin as standard.

\section{Semi-quantitative reverse transcriptase-polymerase chain reaction assay}

Total RNA of $12.5 \mathrm{~d}$ embryos was extracted by TriZol reagent (Gibco, Grand Island, NY, USA). RNA ( $2 \mu \mathrm{g}$ ) was reverse-transcribed with random hexamers by Moloney murine leukaemia virus RT, and then PCR were carried out using the following primers: Hoxc8 5'-GTCCAAGACTTCTTCCACCA-3' (sense); $5^{\prime}$-CCTTGTCCTTCGCTACTGTT-3' (antisense) and glyceraldehyde-3-phosphate dehydrogenase (GAPDH) 5'-TCACTCAAGATTGTCAGCAA-3' (sense); 5'-AGATCCACGACGGACACATT-3' (antisense) generating products of 215 and $308 \mathrm{bp}$ respectively. All PCR reactions consisted of dNTP ( $0.2 \mathrm{mmol} /$ 1), $2 \mu \mathrm{l} \mathrm{cDNA}, 0.25 \mu \mathrm{mol} / \mathrm{l}$ of each primer, $1 \times$ PCR buffer and $0.8 \mathrm{U}$ Taq polymerase. The following cycling profile was used: $5 \mathrm{~min}$ of denaturation at $94^{\circ} \mathrm{C}$ followed by thirty-five cycles of each $1 \mathrm{~min}$ at $94^{\circ} \mathrm{C}$ denaturation, 1 min of annealing (GAPDH $58^{\circ} \mathrm{C}$ and $\operatorname{Hoxc} 857^{\circ} \mathrm{C}$ ) and $1 \mathrm{~min}$ extension at $72^{\circ} \mathrm{C}$, and a final extension step of $10 \mathrm{~min}$ at $72^{\circ} \mathrm{C}$ in a PCR System thermocycler (Whatman, Biometra, Germany). The PCR products were separated on $1.5 \%$ agarose gel and stained with ethidium bromide. Quantification of the Hoxc8 and GAPDH mRNA was performed by scanning the intensities of the ethidium bromide-stained PCR products using the BioDocAnalyse system (Whatman). The Hoxc 8 mRNA levels were standardised relative to GAPDH mRNA.

\section{Western analysis}

Extraction nuclear protein from $12.5 \mathrm{dpc}$ embryos was performed as described previously. The protein concentration was determined by Dc protein assay (BioRad, Richmond, CA, USA). Nuclear protein samples $(50 \mu \mathrm{g})$ were heated for $5 \mathrm{~min}$ at $95^{\circ} \mathrm{C}$ and separated on $12 \%$ SDS-PAGE and transferred to NC membranes (Millipore, Bedford, MA, USA) in tri(hydroxymethyl)-aminomethane-glycine buffer( $\mathrm{pH} \quad 8 \cdot 5)$ plus $20 \%$ methanol. The membranes were blocked overnight in $5 \%$ non-fat milk in tri(hydroxymethyl)-aminomethanebuffer containing $0.1 \%$ Tween-20 and then washed with tri(hydroxymethyl)-aminomethane-buffer. The blots were incubated for $2 \mathrm{~h}$ at room temperature with 1:500 mouse Hoxc8 monoclonal IgG (Covance, Princetown, NJ, USA) and 1:4000 rabbit polyclonal antibody anti-nucleolin (Abcam
Ltd, Cambridge, Cambs, UK), respectively. The blots were washed and then incubated with anti-mouse IgG conjugated with peroxidase (Sigma, St Louis, MO, USA) at 1:10000 dilution. An Amersham ECLTM Detection Kit (GE Healthcare Life Sciences, Little Chalfont, Bucks, UK) provided the chemiluminescence substrate for horseradish peroxidase, and the targeted protein was visualised by autoradiography.

\section{Statistical methods}

The SPSS 12.0 software package (SPSS Inc., Chicago, IL, USA) was used for statistical analysis. Because of its skewed distribution, the medians were used to describe the central tendency of urinary iodine concentration. The Krus$\mathrm{kal}-$ Wallis method was used to test the differences in ranking of urinary iodine concentration. Other data were analysed by a one-way ANOVA and Duncan's test. Significance level was set at $P<0.05$.

\section{Results}

Average daily water consumption, urinary iodine concentration and thyroid hormone level in maternal mice

Average daily water intake was 4.9 (SD 0.8), 4.8 (SD 0.9), 4.8 (SD 1.2), 4.5 (SD 1.3), 4.2 (SD 0.7) and $4.2(\mathrm{SD} \mathrm{1.2)} \mathrm{ml}$ in female mice of $0,1 \cdot 5,3 \cdot 0,6 \cdot 0,12 \cdot 0$ and $24 \cdot 0 \mu \mathrm{g}$ iodine $/ \mathrm{ml}$ groups, respectively. There was no obvious difference among groups. The mouse drinks about $5 \mathrm{ml}$ daily. As for the groups given high doses of iodine, iodinated water was the main source of iodine. So, the daily iodine intake could be about $7 \cdot 5,15,30,60$ and $120 \mu \mathrm{g}$ in the treatment groups, which corresponded to 5-, 10-, 20-, 40- and 80-fold of the adequate iodine intake for mice. The concentration of iodine in urine is currently the most widely used biochemical marker of iodine intake. After exposure to excessive iodine for 4 months, the urinary iodine concentration of female mice increased in a dose-dependent manner ( $r$ 0.96; $P<0.01$; Fig. 1). Compared with the control group, serum total $\mathrm{T}_{4}$

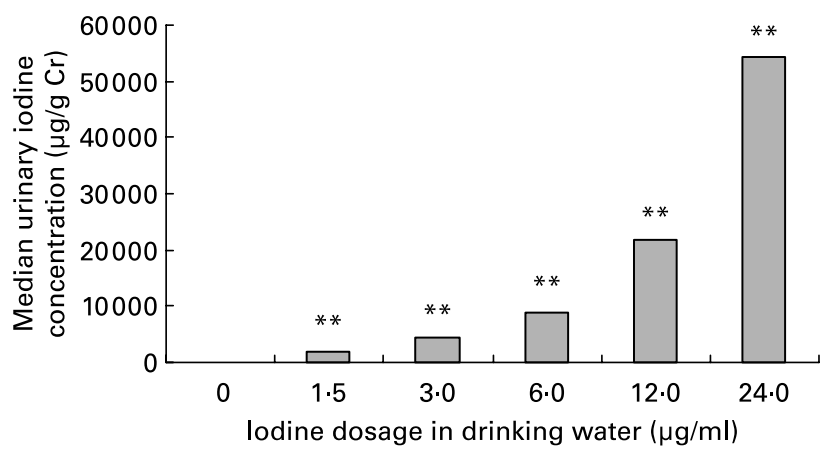

Fig. 1. Effect of excessive iodine exposure on urinary iodine level in female mice. Exposed to different doses of iodine at the levels of $0,1.5,3.0,6.0$, 12.0 and $24.0 \mu \mathrm{g} / \mathrm{ml}$ in drinking water for 4 months, female mice were placed into metabolism cages of four mice each and urine samples of $3 \mathrm{~h}$ in the morning were collected for $3 \mathrm{~d}$ for urinary iodine determination. The urinary iodine:creatinine ratio $(\mu \mathrm{g} / \mathrm{g} \mathrm{Cr}$ ) was used to estimate iodine concentration in urine. Values are medians, each bar representing the median of a group of six samples. ${ }^{* *}$ Median values were significantly different from that of the control group $(P<0.01)$ (Kruskal-Wallis method). 
levels increased and serum total $\mathrm{T}_{3}$ levels decreased significantly in dams when the iodine dose reached $3.0 \mu \mathrm{g} / \mathrm{ml}$, whereas exposure to $1.5 \mu \mathrm{g}$ iodine/ml had no obvious effect on thyroid hormone level (Fig. 2).

Hepatic and renal type 1 deiodinase activity, and placental type 2 and type 3 deiodinase activity assays

An obvious depression of D1 activity in liver and kidney was observed in groups when the exposure iodine dose reached $3.0 \mu \mathrm{g} / \mathrm{ml}$; this showed in a dose-dependent manner (liver: $r-0.402, \quad P<0.01$; kidney: $r-0.276, P<0.05$; Fig. 3 ). High iodine intake had a predominant effect on D2 activity of $12.5 \mathrm{dpc}$ placenta, and no effect on D3 activity (Fig. 4). A dose-dependent reduction of D2 activity was found in groups where the dose was $3.0 \mu \mathrm{g} / \mathrm{ml}$ or above $(r-0.524$; $P<0 \cdot 01)$. Meanwhile, D3 activity was obvious higher than D2 activity in $12.5 \mathrm{dpc}$ placenta.

\section{Hoxc8 messenger ribonucleic acid and protein expression}

In the case of the temporal expression pattern, Hoxc8 was expressed in most of the stages of embryonic development from 8.5 to $17.5 \mathrm{dpc}$ (Kwon et al. 2005). In the present study, a decreasing trend in mRNA abundance was semi-quantified by RT-PCR in $12.5 \mathrm{dpc}$ embryos exposed to excessive iodine (Fig. 5 (A)). Western blot assay indicated that high iodine intake above $1.5 \mu \mathrm{g} / \mathrm{ml}$ induced down regulation of Hoxc8 protein (Fig. 5 (B)).
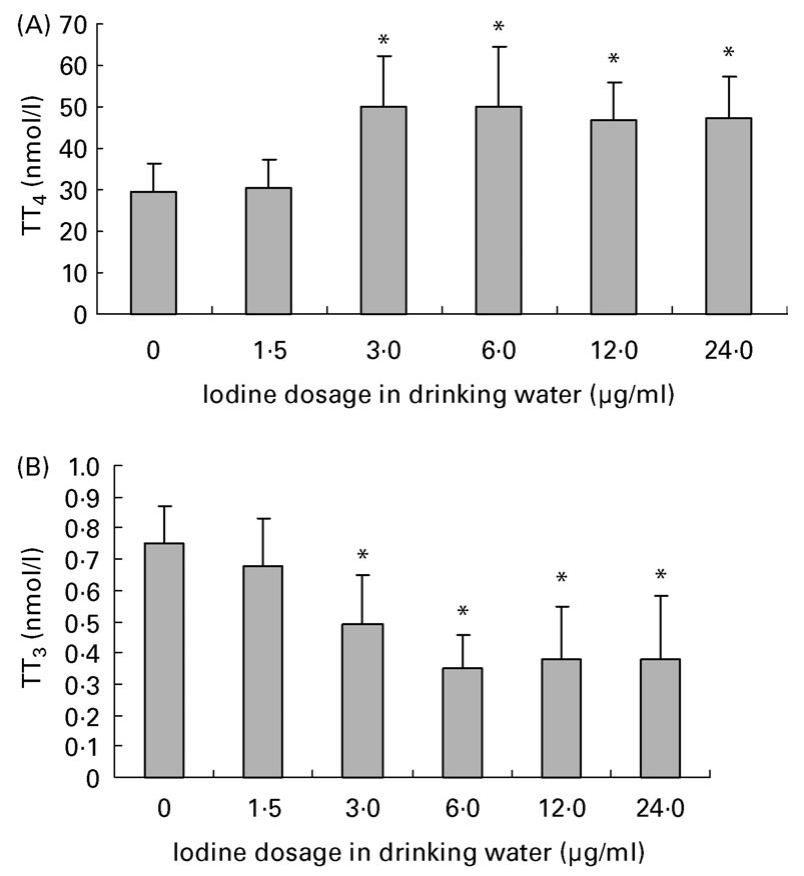

Fig. 2. Effects of excessive iodine exposure on serum thyroid hormone levels in maternal mice. Serum was collected from $12.5 \mathrm{~d}$ postcoitum maternal mice exposed to different doses of iodine at the levels of $0,1.5,3.0,6.0,12.0$ and $24.0 \mu \mathrm{g} / \mathrm{ml}$ in drinking water. Values are means for serum total thyroxine $\left(\mathrm{TT}_{4}\right)$ level $(\mathrm{A})$ and total triiodothyronine $\left(\mathrm{TT}_{3}\right)$ level $(\mathrm{B})$ (n 8), with standard deviations represented by vertical bars. * Mean value was significantly different from that of the control group $(P<0.05)$ (ANOVA and Duncan's test).
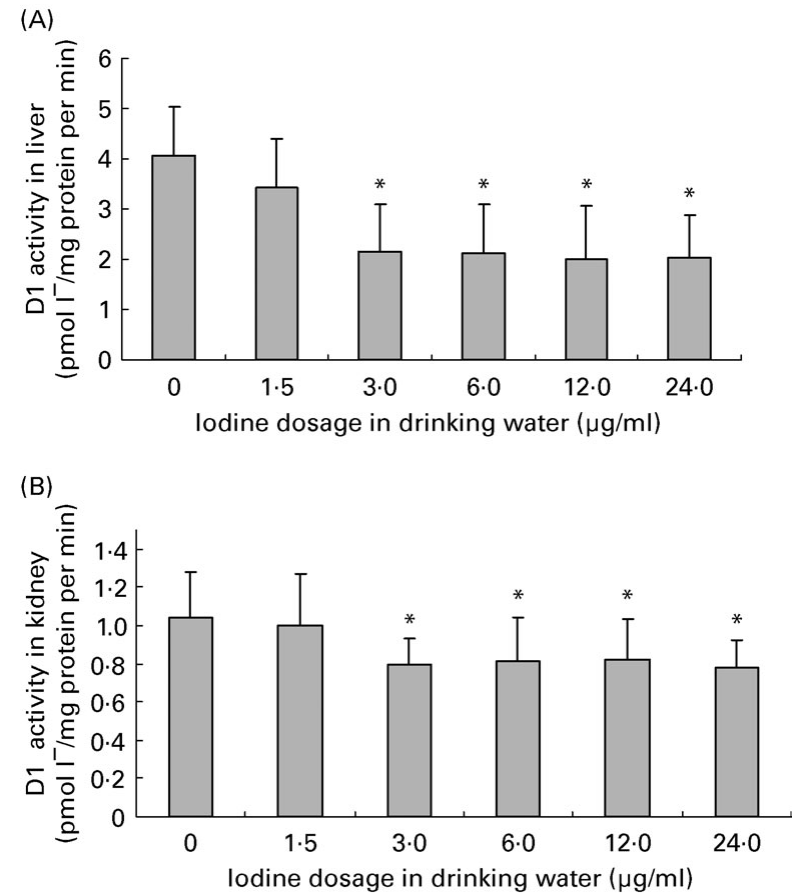

Fig. 3. Effect of excessive iodine exposure on type 1 deiodinase (D1) activity in liver (A) and kidney (B) of maternal mice. Exposed to different doses of iodine at the levels of $0,1.5,3.0,6.0,12.0$ and $24.0 \mu \mathrm{g} / \mathrm{ml}$ in drinking water for 4 months, female mice were mated and killed at $12.5 \mathrm{~d}$ postcoitum. D1 activities of liver and kidney were determined using $\left[{ }^{125} \mathrm{l}\right] \mathrm{r}$-triiodothyronine as substrate. Enzyme activity was expressed as $\mathrm{pmol} \mathrm{I}^{-}$released/mg protein per min of reaction. Values are means for D1 activity in liver (A) and kidney (B) $(n 8)$, with standard deviations represented by vertical bars. * Mean value was significantly different from that of the control group $(P<0.05)$ (ANOVA).

\section{Discussion}

In the present study, excessive iodine treatment resulted in an increase of total $\mathrm{T}_{4}$ and a decrease of total $\mathrm{T}_{3}$, consistent with previous studies (Harjai \& Licata, 1997; Xiang et al. 1999). This change was mainly related to the inhibition of D1 activity in liver and kidney, resulting in a decrease in the generation of $\mathrm{T}_{3}$ from $\mathrm{T}_{4}$. Maternal thyroid hormone levels have an effect on fetal thyroid hormones by means of the placenta, which modulates the transfer of iodine and small but important amounts of thyroid hormones (especially $\mathrm{T}_{4}$ ) from the mother to the fetus (Burrow et al. 1994). The fetal thyroid gland becomes functional at about $17-18 \mathrm{dpc}$ in rodents (Bianco et al. 2002). At $12.5 \mathrm{dpc}$, fetal thyroid hormones come from the maternal circulation by deiodination of $\mathrm{T}_{4}$ through placenta D2. Placental D2 activity is negatively regulated by maternal $\mathrm{T}_{4}$ level (Steinsapir et al. 2000). In the present study, placental D2 activity at $12.5 \mathrm{dpc}$ decreased, showing an inverse relationship with maternal $\mathrm{T}_{4}$ level $(r-0.301 ; P<0.05)$. Placental D2 activity is likely to be of considerable physiological importance for fetal thyroid hormone economy by contributing to the intraplacental $\mathrm{T}_{3}$ content, and possibly to the plasma $\mathrm{T}_{3}$. Placental D3 activity is much higher than that of D2, which could be important for the protection of fetal tissues from elevated $\mathrm{T}_{3}$ levels (Bates et al. 1999). Placental D3 activity showed no significant change after exposure to excessive iodine; the underlying mechanism needs to be elucidated. 
(A)

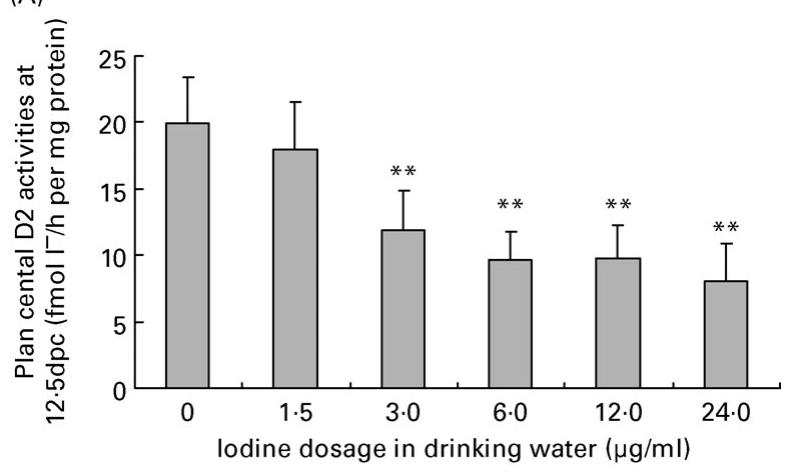

(B)

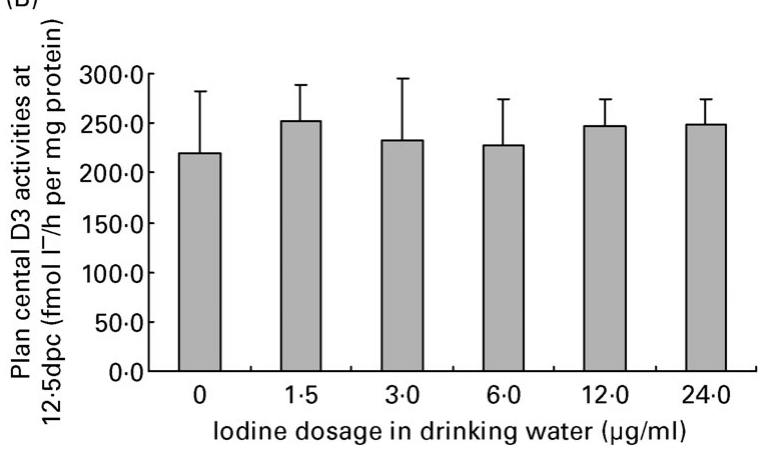

Fig. 4. Effect of excessive iodine exposure on placenta type 2 deiodinase (D2) (A) and type 3 deiodinase (D3) (B) activities at $12.5 \mathrm{~d}$ postcoitum. Exposed to different doses of iodine at the levels of $0,1 \cdot .5,3 \cdot 0,6 \cdot 0,12.0$ and $24.0 \mu \mathrm{g} / \mathrm{ml}$ in drinking water for 4 months, female mice were mated and killed at $12.5 \mathrm{~d}$ postcoitum. Placental D2 and D3 activities were determined using $\left[{ }^{125} \mid\right]$ thyroxine $\left(T_{4}\right)$ and $\left[{ }^{125} \mathrm{I}\right]$ triiodothyronine $\left(\mathrm{T}_{3}\right)$ as substrate, respectively. Enzyme activities were expressed as fmol $\left.{ }^{125}\right|^{-}$released from $\left[{ }^{125} \mid\right] \mathrm{T}_{4}$ (D2) or $\left[{ }^{125} \mathrm{I}\right] \mathrm{T}_{3}$ (D3)/h per mg protein. Values are means for placental D2 (A) and D3 (B) activities ( $n$ 8), with standard deviations represented by vertical bars. ${ }^{* *}$ Mean value was significantly different from that of the control group $(P<0.01)$ (ANOVA).

At $12.5 \mathrm{dpc}$, the mother is the only source of fetal thyroid hormones. After exposure to excessive iodine, $\mathrm{T}_{4}$ was higher but $\mathrm{T}_{3}$ was lower in the serum of maternal mice. At the same time, placental D2 activity decreased. Therefore, thyroid hormone abnormalities - either hypothyroidism or hyperthyroidism may be induced in $12.5 \mathrm{~d}$ embryos. Due to limited sample availability, thyroid hormone levels in the fetuses were not measured in the present study. Nevertheless, several studies have reported that chronic maternal exposure to excessive iodine may cause fetal or neonatal hypothyroidism and goitre (Mehta et al. 1983; Bartalena et al. 2001; Serreaul et al. 2004). In addition, another study (Guo et al. 2006) in our laboratory also found that the progenies of mothers exposed to excessive iodine were hypothyroid. The above evidence has suggested that hypothyroidism might be induced in $12.5 \mathrm{~d}$ embryos of mothers exposed to excessive iodine.

Thyroid hormones are essential for normal skeletal development (Yen, 2001). Regulation of $\mathrm{T}_{3}$ on chondrocytes, osteoblasts and osteoclasts, and the actions of TR isoforms in skeletal development has been reviewed (Bassette \& Williams, 2003). Hypothyroidism may result in growth arrest, delayed bone age and short stature (Yen, 2001). We
(A)

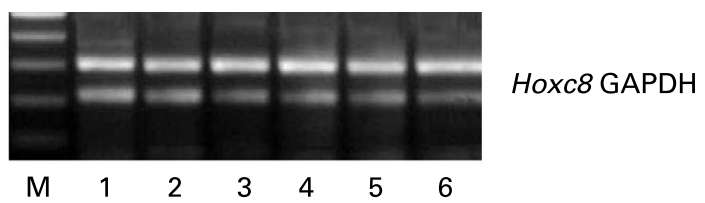

(B)

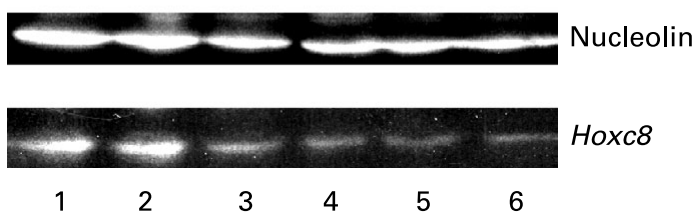

Fig. 5. Effect of excessive iodine exposure on mRNA and protein expressions of Hoxc8 in $12.5 \mathrm{~d}$ postcoitum embryos. Exposed to different doses of iodine at the levels of $0,1.5,3.0,6.0,12.0$ and $24.0 \mu \mathrm{g} / \mathrm{ml}$ in drinking water for 4 months, female mice were mated and killed at $12.5 \mathrm{~d}$ postcoitum. Embryos were collected, and RT-PCR and Western blotting were performed to determining mRNA and protein expressions of Hoxc8. PCR products were visualised by ethidium bromide staining (A). Protein expression was quantified by Western analysis with ECL detection (B) (see Methods). Lane M, DNA marker; GAPDH, glyceraldehyde-3-phosphate dehydrogenase; lanes $1,2,3,4,5$ and 6 represent embryos from groups receiving iodine at $0,1 \cdot 5,3 \cdot 0,6 \cdot 0,12 \cdot 0$ and $24.0 \mu \mathrm{g} / \mathrm{ml}$.

previously observed that excessive iodine exposure increased the incidence of skeletal malformation, especially supernumerary ribs. A similar phenomenon was observed in Hoxc8-/- mice (Akker et al. 2001). Other several lines of evidence also substantiate a role for Hoxc8 in the normal axial skeleton (Belting et al. 1998; Juan \& Ruddle, 2003; Kwon et al. 2005). In the present study, maternal excessive iodine exposure down regulated mRNA and protein expression of Hoxc8 in 12.5 d embryos. Gaur et al. (2001) described a dramatic increase in the expression of the HoxA5 in the heart and aorta of the Mexican axolotl during the process of $\mathrm{T}_{4}$-induced metamorphosis. Disruption of Hoxc8 expression may associate with the fluctuation of thyroid hormone level induced by excessive iodine exposure. Moreover, with a thyroid hormone response element located in the Hoxc8 promoter region, hypothyroidism induced by excessive iodine could reduce Hoxc8 expression through this thyroid hormone response element-dependent pathway. This finding provided a possible explanation for the skeletal malformation induced by excessive exposure. Further studies are needed to provide more direct evidence of Hoxc 8 expression regulation by thyroid hormones through this thyroid hormone response element-dependent pathway.

The mechanism of Hoxc8 modulating bone development has not been clarified. Recently, the identification of downstream targets of Hoxc8 genes found that osteopontin (OPN), also known as secreted phosphoprotein 1, is down regulated by Hoxc8 overexpression in microarray analysis and confirmed by chromatin immunoprecipitation (ChIP) analysis (Lei et al. 2005). OPN is the major non-collagenous bone matrix protein associated with osteoblastic cell adhesion and abundantly expressed during the early stages of osteoblast differentiation. More interestingly, analysis of thyroid hormone responsive gene expression found that $O P N$ expression is also regulated by $\mathrm{T}_{3}$ in osteoblastic cells (Harvey et al. 2003). These findings provide more possible evidence of 
bone development modulated by thyroid hormones through Hox genes, which also need further investigation to verify.

In conclusion, we have demonstrated that excessive iodine exposure induced abnormalities of maternal-fetal thyroid hormone metabolism by affecting deiodinase activities, accompanying down regulation of Hoxc 8 mRNA and protein expression. This mechanism may play a pivotal role in skeletal malformation induced by excessive iodine, and provide a new clue to study the relationship between nutrient-iodine or thyroid hormones and Hox gene expression pattern.

\section{Acknowledgements}

The present study was supported by the National Natural Science Foundation of China, no. 30230330.

\section{References}

Akker E, Fromental-Ramain C, Graaff W, Mouellic HL, Brûlet P, Chambon P \& Deschamps J (2001) Axial skeletal patterning in mice lacking all paralogous group 8 Hox genes. Development 128, 1911-1921.

Awgulewitsch A, Bieberich C, Bogarad L, Shashikant C \& Ruddle FH (1990) Structural analysis of the Hox-3.1 transcription unit and the Hox-3.2-Hox-3.1 intergenic region. Proc Natl Acad Sci U S A 87, 6428-6432.

Banker DE \& Eisenman RN (1993) Thyroid hormone receptor can modulate retinoic acid-mediated axis formation in frog embryogenesis. Mol Cell Endocrinol 13, 7540-7552.

Bartalena L, Bogazzi F \& Braverman LE (2001) Effects of amiodarone administration during pregnancy on neonatal thyroid function and subsequent neurodevelopment. $J$ Endocrinol Invest 24, $275-283$

Bassette JHD \& Williams GR (2003) The molecular actions of thyroid hormone in bone. Trends Endocrinol Metab 14, 356-364.

Bates JM, St Germain DL \& Galton VA (1999) Expression profiles of the three iodothyronine deiodinases D1, D2 and D3 in the developing rat. Endocrinology 140, 844-851.

Bednarczuk T, Pietrzykowski A, Slon M \& Nauman A (1993) Pharmacologic effect of excess iodine on type I thyroxine $5^{\prime}$-deiodinase activity in rat thyroid. Endokrynol Pol 44, 405-412.

Belting HG, Shashikant CS \& Ruddle FH (1998) Multiple phases of expression and regulation of mouse Hoxc 8 during early embryogenesis. J Exp Zool 282, 196-222.

Bianco AC, Salvatore D, Gereben B, Berry MJ \& Larsen PR (2002) Biochemistry, cellular and molecular biology, and physiological roles of the iodothyronine selenodeiodinases. Endocr Rev 23, $38-89$.

Bradford MM (1976) A rapid and sensitive for the quantitation of microgram quantitites of protein utilizing the principle of protein-dye binding. Anal Biochem 72, 248-254.

Burrow GN, Fisher DA \& Larsen PR (1994) Maternal and fetal thyroid function. N Engl J Med 331, 1072-1078.

Delange F \& Lecomte P (2000) Iodine supplementation: benefits outweigh risks. Drug Saf 22, 89-95.

Fischer PWF, L'Abbé MR \& Giroux A (1986) Colorimetric determination of total iodine in foods by iodide-catalyzed reduction of $\mathrm{Ce}^{4+}$. Anal Chem 69, 687-689.

Gaur A, Zajdel RW, Bhatia R, Isitmangil G, Denz CR, Robertson DR, Lemanski LF \& Dube DK (2001) Expression of HoxA5 in the heart is upregulated during thyroxin-induced metamorphosis of the Mexican axolotl (Ambystoma mexicanum). Cardiovasc Toxicol 1, 225-235.
Glinoer D (1997) Maternal and fetal impact of chronic iodine deficiency. Clin Obstet Gynecol 40, 102-116.

Guo HL, Xu J, Yang XF, Hou XH, Chen XY \& Sun XF (2006) Effect of excess iodine on function of thyroid in progeny of mice and intervention of selenium. Chin J Public Health 22, 930-931.

Harjai KJ \& Licata AA (1997) Effects of amiodarone on thyroid function. Ann Intern Med 26, 63-73.

Harvey CB, Stevens DA, Williams AJ, Jackson DJ, O'Shea P \& Williams GR (2003) Analysis of thyroid hormone responsive gene expression in osteoblastic cells. Mol Cell Endocrinol 213, $87-97$.

Hotz CS, Belonje Bitzpatrick DW \& L'abbe MR (1996) A method for the determination of type I iodothyronine deiodinase activity in liver and kidney using ${ }^{125}$ I-labelled reverse triiodothyronine as a substrate. Clin Biochem 29, 451-456.

Juan AH \& Ruddle FH (2003) Enhancer timing of Hox gene expression: deletion of the endogenous Hoxc8 early enhancer. Development 130, 4823-4834.

Konno N, Makita H, Yuri K, lizuka N, Kawasaki K, Norimichi K, Horini M, Kenji Y, Norio I \& Kimio K (1994) Association between dietary iodine intake and prevalence of subclinical hypothyroidism in the coastal regions of Japan. J Clin Endocrinol Metab 78, 393-397.

Koopdonk-Kool JM, de Vijlder JJM, Veenboer GJM, Ris-stalpers C, Kok JH, Vulsma T, Boer K \& Visser TJ (1996) Type II and type III deiodinase activity in human placenta as a function of gestational age. J Clin Endocrinol Metab 81, 2154-2158.

Kumar R \& Thompson BE (1999) The structure of the nuclear hormone receptors. Steroids 64, 310-319.

Kwon Y, Shin J, Park HW \& Kim MH (2005) Dynamic expression pattern of Hoxc8 during mouse early embryogenesis. Anat Rec 283A, 187-192.

Lei H, Wang H, Juan AH \& Ruddle FH (2005) The identification of Hoxc8 target genes. Proc Natl Acad Sci U S A 102, 2420-2424.

Lufkin T (1996) Transcriptional control of Hox genes in the vertebrate nervous system. Curr Opin Genet Dev 6, 575-580.

Markou K, Georgopoulos N, Kyriazopoulou V \& Vagenakis AG (2001) Iodine-induced hypothyroidism. Thyroid 11, 501-510.

Martinez P \& Amemiya CT (2002) Genomics of the HOX gene cluster. Comp Biochem Physiol 133B, 571-580.

Martino E, Bartalena L, Bogazzi F \& Braverman LE (2001) The effects of amiodarone on the thyroid. Endocr Rev 22, 240-254.

Mehta PS, Mehta SJ \& Vorherr H (1983) Congenital iodide goiter and hypothyroidism: a review. Obstet Gynecol Surv 38, 237-247.

Morreale de Escobar G, Pastor R, Obregon MJ \& Escobar del Rey F (1985) Effects of maternal hypothyroidism on the weight and thyroid hormone content of rat embryonic tissues, before and after onset of fetal thyroid function. Endocrinology 117, 1890-1900.

Obregon MJ, Mallol J, Pastor R, Morreale de Escobar G, Escobar del Rey F, et al. (1984) L-Thyroxine and 3,5,3'-triiodo-L-thyronine in rat embryos before onset of fetal thyroid function. Endocrinology 114, 305-307.

Roti E \& Uberti ED (2001) Iodine excess and hyperthyroidism. Thyroid 11, 493-500.

Santini F, Chiovato L \& Ghirri P (1999) Serum iodothyronines in the human fetus and the newborn: evidence for an important role of placenta in fetal thyroid hormone homeostasis. J Clin Endocrinol Metab 84, 493-498.

Serreaul R, Polack M \& Leger J (2004) Fetal thyroid goiter after massive iodine exposure. Prenat Diagn 24, 745-754.

Steinsapir J, Bianco AC, Buettner C, Harney J \& Larsen PR (2000) Substrate-induced down-regulation of human type 2 deiodinase (hD2) is mediated through proteasomal degradation and requires interaction with the enzyme's active center. Endocrinology 141, $1127-1135$.

Utiger RD (1999) Maternal hypothyroidism and fetal development. N Engl J Med 341, 601-602. 
Wolff J (2001) Physiology and pharmacology of iodized oil in goiter prophylaxis. Medicine 80, 20-36.

Xiang JM, Chen ZP, Di HJ, Yan YQ \& Chen QY (1999) Effects of iodine excess on antioxidizing ability of mice. Chin J Endem 4, 245-248.

Yang XF, Xu J, Hou XH, Guo HL, Hao LP, Yao P, Liu LG \& Sun XF (2006) Developmental toxic effects of chronic exposure to high doses of iodine in the mouse. Reprod Toxicol 22, 725-730.

Yen PM (2001) Physiological and molecular basis of thyroid hormone action. Physiol Rev 81, 1097-1142.

Zhao JK, Chen ZP \& Maberly GF (1998) Iodine-rich drinking water of natural origin in China. Lancet 352, 2024. 